\title{
Antioxidant Activity of the Germinated Seed of Four Varieties of Amaranthus caudatus L. from Peru
}

\author{
Enrique Javier Aguilar-Felices', Marta Romero-Viacava², Edwin Enciso-Roca', Oscar Herrera-Calderon ${ }^{3 *}$, \\ Pablo Común-Ventura' ${ }^{1}$, Ricardo Ángel Yuli-Posadas ${ }^{4}$, Luz Chacaltana-Ramos ${ }^{5}$, Bertha Pari-Olarte ${ }^{5}$
}

\section{Enrique Javier Aguilar- \\ Felices', Marta Romero- \\ Viacava ${ }^{2}$, Edwin Enciso-Roca', \\ Oscar Herrera-Calderon ${ }^{3, *}$, \\ Pablo Común-Ventura ${ }^{3}$, \\ Ricardo Yuli-Posadas ${ }^{4}$, Luz \\ Chacaltana-Ramos ${ }^{5}$, Bertha \\ Pari-Olarte $^{5}$}

'Laboratory of Pharmacognosy, Faculty of Health Sciences, Universidad Nacional de San Cristóbal de Huamanga, Ayacucho, PERU.

${ }^{2}$ Laboratory of Botany, Faculty of Biological Sciences, Universidad Nacional San Cristóbal de Huamanga, Ayacucho, PERU.

${ }^{3}$ Laboratory of Pharmacognosy and Traditional Medicine, Faculty of Pharmacy and Biochemistry, Universidad Nacional Mayor de San Marcos, Lima, PERU. ${ }^{4}$ Universidad Continental, Huancayo, PERU. ${ }^{5}$ Faculty of Pharmacy and Biochemistry, Universidad Nacional San Luis Gonzaga, Ica, PERU.

\section{Correspondence}

\section{Dr. Oscar Herrera Calderon}

Department of Pharmacology, Bromatology, Toxicology, Faculty of Pharmacy and Biochemistry, Universidad Nacional Mayor de San Marcos, Lima, PERU.

Tel. +51956550510

E-mail: oherreraca@unmsm.edu.pe

History

- Submission Date: 25-03-2019;

- Review completed: 12-04-2019;

- Accepted Date: 19-04-2019.

DOI : 10.5530/pj.2019.11.93

Article Available online

http://www.phcogj.com/v11/i3

Copyright

(C) 2019 Phcogj.Com. This is an openaccess article distributed under the term of the Creative Commons Attribution 4.0 International license.

\begin{abstract}
Introduction: The objective of this study was to determine the antioxidant activity of four varieties of germinated seeds of Centenario, Cristalino, Oscar Blanco and Taray of Amaranthus caudatus L. compared to non-germinated seeds. Material and Methods: The determination of total phenols was carried out by using Folin-Ciocalteu, total flavonoids by the method of aluminum chloride and the antioxidant activity by the methods of DPPH, ABTS and FRAP. Results: Cristalino variety had the highest germination $(3.0 \mathrm{~cm}$ of height) and all varieties had a $50 \%$ germination rate. Cristalino and Taray varieties had the highest content of total phenolics (GAE 32.92 and $35.00 \mathrm{mg} / \mathrm{g}$ sample), Cristalino variety had higher content of flavonoids (580.95 $\mathrm{mg} \mathrm{QE} / \mathrm{g}$ ) ( $\mathrm{P}<0.05)$; Cristalino and Taray varieties showed greater scavenging activity of DPPH radical (151.85 and $151.38 \mathrm{mg}$ TE/g sample), ABTS (178.09 and $180.18 \mathrm{mg}$ TE/g sample); and reducing capacity of the ferric ion (FRAP) (132.75 and $136.42 \mathrm{mg}$ TE/g of sample). Conclusion: Sprouts of Cristalino and Taray varieties had higher antioxidant activity than non-germinated seeds and they are directly related to higher content of total phenols and flavonoids.
\end{abstract}

Key words: Amaranthus caudatus L., germinated seeds, phenolics, antioxidant activity.

\section{INTRODUCTION}

The genus Amaranthus is highly diverse, includes about 70 species of which the most important are Amaranthus cruentus, Amaranthus caudatus and Amaranthus hypochondriacus. They are valued for their high protein content and many nutraceutical properties. Several chemical analyzes have shown that accumulate various types of secondary metabolites, especially phenolic acids, flavonoids and other polyphenols, produced by high antioxidant activity. This activity has been linked to epidemiologically with diseases produced by the stress oxidative, such as cancer and cardiovascular diseases. Amaranthus caudatus L. particularly has reported the presence of flavonoids, phenolic acids, tannins, steroid and triterpenoid saponins, amarantolidosidos, carotenoids and phytates. While phenylpropanoids present in seeds are: total phenolic acids, $p$-coumaric acid, ferulic acid, protocatechuic acid, $p$-hydroxybenzoic acid, caffeic acid, salicylic acid, flavonoids like rutin and quercetin: and germinated the presence of protocatechuic acid.

Amaranthus caudatus L. is a slightly woody annual, herbaceous, whose colors of panicles varies of green, yellow and red to purple. Inflorescences can be amarantiform or glomerulate, they are very attractive and can vary from upright to falls or prostrate with varied colors. The seed is very small, smooth, shiny, generally white in color, although there is yellow, red and wild amaranth are black. ${ }^{2}$
Also, the seeds are almost globose, smooth, shiny, pale ivory dark brown, or reddish. ${ }^{3}$ Selected varieties are mainly achieved in Cusco, based on genetic material from Tarija (Bolivia), such as varieties Vietmayer Noel and Oscar Blanco, they are the most widespread. Consuelo variety is the recent selection. The Ayacuchana variety selected in Ayacucho, has shown very good yields about $3000 \mathrm{~kg} / \mathrm{ha}$. In Cajamarca, they have been obtained varieties such as San Luis, Otusco and Red Cajamarca. In Bolivia, it is selected Cahuayuma variety of excellent performance and the varieties: Pairumani 1 and Pairumani 2 from Cochabamba. ${ }^{4}$ It has reported the presence of phenolic compounds in seeds of two varieties of Amaranthus cruentus L. and antioxidant activity. ${ }^{5}$ It has also determined the content of total phenols, phenolic acids and antioxidant activity of Amaranthus caudatus L. seeds and Amaranthus paniculatus by the bleaching method of $\beta$ - carotene seeds. ${ }^{5}$ Also, it has been reported the phenolic content and antioxidant activity of Amaranthus caudatus $\mathrm{L}$. seeds, when are affected by cooking and germinated. ${ }^{6}$

The methods used in determining antioxidant activity of chemical compounds present in plants, have evolved as they have better techniques, which are more selective to detect the antioxidant capacity of water-soluble compounds and soluble. Several authors have reviewed these methods in order to analize which are the best to determine the antioxidant capacity in foods and dietary supplements. ${ }^{7,8}$
Cite this article: Aguilar-Felices EJ, Romero-Viacava M, Enciso-Roca E, Herrera-Calderon O, Común-Ventura P, Yuli-Posadas RA, et al. Antioxidant Activity of the Germinated Seed of Four Varieties of Amaranthus caudatus L. from Peru. Pharmacog J. 2019;11(3):588-93. 
In the process of obtaining the sprouts, the germination percentage is determined as an indicator of performance, for which germinated seeds of Chenopodium quinoa Willd "Quinoa" is referenced as model. ${ }^{9}$

This research was conducted considering as general objective to determine the content of phenolics and antioxidant activity of four varieties of sprouts of Amaranthus caudatus L. collected in the Experimental Station of the National Institute for Agricultural Research - Ayacucho - Peru.

\section{MATERIAL AND METHODS}

\section{Collection plant}

This research was conducted at the Laboratory of Pharmacognosy, Department of Pharmacy, Faculty of Health Sciences and the Laboratory of Botany of the Faculty of Biological Sciences of the Universidad Nacional San Cristobal de Huamanga, during the months of January and December 2017.

$164 \mathrm{~g}$ seeds of the variety "Taray", $197 \mathrm{~g}$ seed of the variety "Oscar Blanco", $228 \mathrm{~g}$ seed of the variety "Cristalino", $151 \mathrm{~g}$ seed of the variety "Centenario" were provided and certified by the National Institute for Agricultural Research and Experimentation of Ayacucho (INIEA Ayacucho). The seeds were in good condition.

\section{Obtaining sprouts of Amaranthus caudatus L.}

$10 \mathrm{~g}$ seed of each variety were washed with hypochlorite $0.02 \%(\mathrm{w} / \mathrm{v})$ for 20 minutes, and several times with distilled water. Next, they were placed on absorbent paper moistened with distilled water in glass. The seeds were incubated at $37^{\circ} \mathrm{C}$ from 4 to 6 days until the germinated. Then, it was dried at $40^{\circ} \mathrm{C}$ for 24 hours, then crushed using a porcelain mortar and stored at below $0{ }^{\circ} \mathrm{C}$ until further use. ${ }^{10}$

The length of germinated was determined using a rule, recording the length in $\mathrm{cm}$. Also, the germination percentage was determined, ${ }^{11}$ Using the following formula:

Percentage of germination $(\%)=\frac{\text { number of germinated seeds }}{\text { total number of seeds at the beginning }} \times 100$

Non-germinated seeds were dried at $40^{\circ} \mathrm{C}$ in an oven and then were crushed using a porcelain mortar until a fine powder, which were stored in amber vials until analysis.

\section{Obtaining extracts}

Five grams of germinated seed and seed non-germinated were extracted with $50 \mathrm{~mL}$ of methanol (1:10) using a magnetic stirrer for 4 hours. It was centrifuged at $3000 \mathrm{rpm}$ for 30 minutes, the supernatant was recovered and poured into a flask volumeter of $50 \mathrm{~mL}$ volume and carried with methanol. Each of the extracts was kept refrigerated until further use. $^{12}$

\section{Determination of total phenols}

The total phenolic content was determined using the Folin - Ciocalteu, following the method described by Hossain et al. ${ }^{13} 50 \mathrm{uL}$ of extracts obtained from germinated and non-germinated seeds were diluted and mixed with $0.5 \mathrm{~mL}$ of Folin - Ciocalteu and $2.5 \mathrm{~mL}$ of $1 \mathrm{~N}$ sodium carbonate solution 5\%. The mixture was incubated in the dark for 40 minutes at room temperature $\left(20^{\circ} \mathrm{C}\right)$. After incubation, the absorbance was measured at $725 \mathrm{~nm}$ using a UV - Vis GENESYS 6. A calibration curve with gallic acid was prepared $(0.0 ; 0.05 ; 0.10 ; 0.15 ; 0.20 ; 0.25 ; 0.30$ $\mathrm{mg} / \mathrm{mL}$ ). The results were expressed in $\mathrm{mg}$ gallic acid equivalents per gram of sample (mg GAE/g sample).

\section{Determination of Flavonoids}

The flavonoid content was determined using the method described by Arroyo-Acevedo et al., ${ }^{14} 0.50 \mathrm{~mL}$ of extract was mixed with $0.50 \mathrm{~mL}$ of distilled water and $0.15 \mathrm{~mL}$ of sodium nitrite solution $5 \%$ in a test tube, then, mixed with a Vortex. After 5 minutes, $0.15 \mathrm{~mL}$ of solution of aluminum chloride $10 \%$ was added and mixed with a Vortex. After 6 minutes, $2.0 \mathrm{~mL}$ of sodium hydroxide $4 \%$ was added to the mixture. Immediately, the solution was made up to $5.0 \mathrm{~mL}$ with distilled water and mixed with a Vortex. The absorbance of the final mixture was determined at $510 \mathrm{~nm}$ against a blank reaction with spectrophotometer UV - Vis GENESYS 6. A calibration curve was prepared with quercetin (8.0: $16.0 ; 24.0 ; 32.0 ; 40.0 \mathrm{ug} / \mathrm{mL})$. The flavonoid content of the extracts was expressed as $\mathrm{mg}$ quercetin equivalents/g of sample ( $\mathrm{mg}$ $\mathrm{QE} / \mathrm{g})$.

\section{Determination of antioxidant activity by the method of free radical 1,1-diphenyl - picryl - hidrazyl (DPPH)}

The method described by Hossain et al. ${ }^{15}$ In summary, an aliquot of the extract $(50 \mu \mathrm{L})$ was added to $1950 \mathrm{uL}$ of a methanol solution $(100 \mu \mathrm{M})$ $\mathrm{DPPH}$ free radical. After stirring, the mixture was incubated in the dark for 30 minutes and the absorbance was measured at $517 \mathrm{~nm}$ in a UV Vis GENESYS 6 . The percentage of scavenging free radical activity was calculated according to the following equation:

Inhibition of DPPH radical (\%) $=\left[\frac{A_{D P P H}-A_{M P}}{A_{D P P H}}\right] \times 100$

A standard curve with Trolox $(25-800 \mu \mathrm{M})$ was prepared. The results were expressed as mg equivalent Trolox/g of sample (mg TE/g of sample).

Determination of antioxidant activity by the method of the cation radical of 2,2'-azinobis acid-(3ethylbenzothiazoline)-6-sulfonic acid (ABTS+')

The procedure described by Uddin et al. ${ }^{16}$ A solution pattern (SP) consisting of $7.4 \mathrm{mM}$ of ABTS and $2.6 \mathrm{mM}$ of potassium persulfate are allowed to react for 12 hours. The working solution (WS) was prepared from $1 \mathrm{~mL}$ of WS dissolved in methanol and the absorbance was adjusted to $1.1 \pm 0.02 \mathrm{~mL}$, diluted with methanol at a wavelength of 734 $\mathrm{nm}$. The sample $(150 \mathrm{uL})$ was mixed with $2850 \mathrm{uL}$ of ABTS solution and allowed to react in the dark for 2 hours and the absorbance at $734 \mathrm{~nm}$ was read in a spectrophotometer GENESYS 6 . A standard curve with Trolox was prepared $(25-600 \mathrm{mg})$. The results were expressed as $\mathrm{mg}$ equivalent Trolox/g of sample (mg TE/g of sample).

\section{Determination of antioxidant activity by the method of reduced iron (FRAP)}

It was performed according to the procedure described by Herrera et al. ${ }^{17}$ The standard solution includes $300 \mathrm{mM}$ acetate buffer $\mathrm{pH} 3.6 ; 10$ $\mathrm{mM} \mathrm{2,4,6} \mathrm{-} \mathrm{tripyridyl-triazine} \mathrm{(TPTZ)} \mathrm{dissolved} \mathrm{in} \mathrm{a} \mathrm{solution} \mathrm{of} \mathrm{HCl}$ $40 \mathrm{mM}$ Y $20 \mathrm{mM} \mathrm{FeCl} 3.6 \mathrm{H}_{2} \mathrm{O}$ solution. The working solution (WS) was obtained by mixing and heating to $37^{\circ} \mathrm{C}, 25 \mathrm{~mL}$ of acetate buffer with $2.5 \mathrm{~mL}$ TPTZ solution and $2.5 \mathrm{ml}$ of $\mathrm{FeCl}_{3}$ solution. $150 \mathrm{uL}$ of sample was mixed with $2850 \mathrm{uL}$ of WS solution, allowed to react for 30 minutes and the absorbance at $593 \mathrm{~nm}$ was read in a spectrophotometer GENESYS 6. A standard curve with Trolox (25-800 mg) was prepared. The results were expressed as mg equivalent Trolox/g of sample (mg $\mathrm{TE} / \mathrm{g}$ of sample).

\section{Analysis of data}

The data obtained are presented as mean \pm standard deviation (SD). All experiments were done in triplicate. The differences between the 
means of each species were analyzed by analysis of variance test factor and Tukey multiple comparisons; and differences between germinated and non-germinated seeds, by an analysis of variance of two factors; all with a confidence level of $95 \%(\alpha=0.05)$ using the statistical package version 20 SPPS.

\section{RESULTS}

Tables 1-3.

\section{DISCUSSION}

Cristalalino variety of Amaranthus caudatus L. was reaching higher and the variety Taray lower height which reached during the germination process (Table 1). Germination conditions were 100 seeds, average temperature of $37^{\circ} \mathrm{C}$ and the germination period was 6 days. There is a report of seed germination of Amaranthus caudatus L. in 6 days, for which the variety INIAP Ecuador was used; while in our research four varieties were evaluated and all showed the same period of germination. The germination period of another Andean grain Chenopodium quinoa was three days. ${ }^{18}$ This can be explained by the morphological characteristics of grain apparently the cover of Amaranthus caudatus L. seeds is thicker and takes longer soften the protective cover making possible the interaction of water with the nutritional starch. ${ }^{19}$

Table 2 shows that the germinated seed of Centenario, Cristalino, Oscar Blanco and Taray varieties have higher content of total phenols and flavonoids compared to non-germinated seeds. In regard to total phenols, it was increased 2.9 times in the variety Oscar Blanco to 5.5 times in the variety Taray. Also, the variety Taray has higher content of phenolics and variety Oscar Blanco had a lower content. The total phenolic content in an ethanolic extract of Amaranthus caudatus seeds L., determined by the Folin-Ciocalteu was $39.17 \mathrm{mg} / 100 \mathrm{~g}$ sample, without reporting the variety used also quantitated content free by high performance liquid chromatography resolution reverse phase (RP-HPLC) phenolic acids, for protocatechuic acid $(4.65 \mathrm{mg} / \mathrm{g}$ ), p-hydroxybenzoic acid $(20.89 \mathrm{mg} / \mathrm{g})$, caffeic acid $(55,79 \mathrm{mg} / \mathrm{g})$, p-coumaric acid $(5.20 \mathrm{~g} / \mathrm{g})$, ferulic acid $(18.41 \mathrm{mg} / \mathrm{g})$ and salicylic acid $(1.92 \mathrm{~g} / \mathrm{g})$ respectively, a total of $106.86 \mathrm{~g} / \mathrm{g}$ seed phenolic acids. In another study, the polyphenol content reported in seeds and germinated seeds of Amaranthus caudatus L. using the Folin-Ciocalteu, being at $21.2 \pm 2.3 \mathrm{mg}$ EAG/100 g dry seeds sample and germinated seeds the $82.2 \pm 4.6 \mathrm{mg}$ EAG/100 g dry sample, respectively. ${ }^{20}$ However, they reported that, in the germinating seed, the phenolic content increased to four times, respect to non-germinated seeds.

In our case, the average increase in four varieties were 4.2 times. Also, we had the highest average recovery, since our results are expressed by $g$ sample and theirs by $100 \mathrm{~g}$ shows. This could be explained because they used only $1.25 \mathrm{~g}$ sample in $25 \mathrm{~mL}$ of methanol, while in our case we used $5.0 \mathrm{~g}$ sample in $50 \mathrm{~mL}$ of methanol. The influence of cultivar on total phenol content in the seeds of Amaranthus caudatus L., using the FolinCiocalteu was determined for the Golden Giant, Rawa, Annapurna, Oscar Blanco and Konitz varieties grown in the Research Center for Plant production of the Slovak Republic, as expressed as mg EAG/kg dry matter were to Golden Giant $(2548.75 \pm 114.75)$, Rawa (1381.05 \pm 77.68), Annapurna ( $\pm 2869.9074 .29)$, Oscar Blanco (1634.10 \pm 61.51$)$ and Koniz $(1807 \pm 128.68)$ respectively. ${ }^{21}$

We report for the variety Oscar Blanco contains $7.20 \mathrm{mg} / \mathrm{g}$ dry sample and they report an equivalent of $1,634 \mathrm{mg} / \mathrm{g}$ dry sample, which

Table 1: Height of sprout and germination percentage of the seeds of four varieties of Amaranthus caudatus L.

\begin{tabular}{ccc}
\hline Variety & Height $(\mathrm{cm})$ & Germination (\%) \\
\hline Oscar Blanco & $1.5 \pm 0.04$ & 50 \\
Cristalino & $3.0 \pm 0.02$ & 50 \\
Centenario & $2.0 \pm 0.01$ & 50 \\
Taray & $1.0 \pm 0.01$ & 50 \\
\hline
\end{tabular}

Table 2: Contents of total phenols and flavonoids of non-germinated and germinated seeds of four varieties of Amaranthus caudatus $L$.

\begin{tabular}{|c|c|c|c|c|}
\hline \multirow[t]{2}{*}{ Variety } & \multicolumn{2}{|c|}{$\begin{array}{c}\text { Total phenols } \\
\text { (Mg GAE/g of sample) }\end{array}$} & \multicolumn{2}{|c|}{$\begin{array}{c}\text { Flavonoids } \\
\text { (QE mg/g sample) })^{* *}\end{array}$} \\
\hline & Non-germinated & germinated & Non-germinated & germinated \\
\hline Centenario & $5.64 \pm 0.5$ & $20.83 \pm 0.6^{*}$ & $156.71 \pm 0.1$ & $228.57 \pm 0.2^{*}$ \\
\hline Cristalino & $6.78 \pm 0.3$ & $32.92 \pm 0.5^{*}$ & $212.55 \pm 0.2$ & $580.95 \pm 0.1^{* *}$ \\
\hline Oscar Blanco & $7.20 \pm 0.1$ & $19.94 \pm 0.5^{*}$ & $196.54 \pm 0.1$ & $467.10 \pm 0.1^{* *}$ \\
\hline Taray & $6.36 \pm 0.1$ & $35.00 \pm 0.8$ & $295.57 \pm 0.1$ & $230.74 \pm 0.1^{*}$ \\
\hline
\end{tabular}

${ }^{*} \mathrm{P}<0.05$

${ }^{* *} \mathrm{P}<0.01$

Table 3: DPPH scavenging capacity, and reducing iron ABTS (FRAP) of phenolic compounds present in the non-germinated seeds germinated and four varieties of Amaranthus caudatus L. "Amaranth".

\begin{tabular}{|c|c|c|c|c|c|c|}
\hline \multirow[t]{2}{*}{ Variety } & \multicolumn{2}{|c|}{$\begin{array}{c}\text { Antioxidant capacity } \\
\text { DPPH } \\
\text { (mg TE/g of sample)* }^{*}\end{array}$} & \multicolumn{2}{|c|}{$\begin{array}{c}\text { Antioxidant capacity } \\
\text { ABTS } \\
\text { (mg TE/g sample) }{ }^{* * *}\end{array}$} & \multicolumn{2}{|c|}{$\begin{array}{l}\text { Reducing capacity } \\
\text { iron (FRAP) } \\
\text { (mg TE/g sample) }^{* * *}\end{array}$} \\
\hline & Non-germinated & germinated & Non-germinated & germinated & Non-germinated & germinated \\
\hline Centenario & $98.73 \pm 0.2$ & $149,62 \pm 4.5^{*}$ & $72.45 \pm 5.0$ & $155.94 \pm 10.0^{*}$ & $51.05 \pm 1.1$ & $102,38 \pm 6.0^{*}$ \\
\hline Cristalino & $107.85 \pm 0.3$ & $151.85 \pm 5.1^{* * *}$ & $75,99 \pm 3.0$ & $178.09 \pm 7.1^{* *}$ & $67.63 \pm 1.1$ & $132.75 \pm 5.1^{* *}$ \\
\hline Oscar Blanco & $108.91 \pm 0.5$ & $150.09 \pm 6.0^{* *}$ & $84.90 \pm 5.0$ & $164.06 \pm 7.6^{*}$ & $65.11 \pm 3.0$ & $110.47 \pm 09.0$ \\
\hline Taray & $99.61 \pm 0.1$ & $151.38 \pm 5.1^{* * *}$ & $69.05 \pm 3.0$ & $180.18 \pm 8.0^{* * *}$ & $54.28 \pm 1.0$ & $136.42 \pm 8.0^{* *}$ \\
\hline
\end{tabular}

${ }^{*} \mathrm{P}<0.05$

${ }^{* *} \mathrm{P}<0.01$

${ }^{* * *} \mathrm{P}<0.001$ 
represents about 4.4 times in our study. The reason could be that this species is native to the Andes and can influence its genetics and biochemistry, leading to increased production of phenolic compounds.

Regarding the content of flavonoids, it is observed that the germinated seed of Centenario, Cristalino, Oscar Blanco and Taray varieties have higher total flavonoid content compared to seeds without germinating. Also, the Cristalino variety has higher content of flavonoids and variety Taray the lower content. Content was increased 0.8 times for variety Taray and 2.7 times for Cristalino variety, averaging 1.8 times

Table 3 shows that the germinated seed of Centenario, Cristalino, Oscar Blanco and Taray varieties had greater scavenging activity of the free radical DPPH free radical ABTS and iron reducer (FRAP), compared to seeds without germinate. In the case of DPPH radical scavenging activity, variety Oscar Blanco had the highest scavenging activity and variety of lower activity Centenario. The difference between varieties was significant $(\mathrm{p}<0.05)$. It was also noted that the Centenario and white varieties Oscar had the lowest sequestering capacity; and Tamarisk and Cristalino varieties had the highest scavenging activity. Furthermore, when comparing the scavenging activity between seeds was performed non-germinated and germinated seed, a highly significant difference $(\mathrm{p}<0,05)$. In a report in which the variety is not required, the free radical scavenging ability DPPH in seeds $(28.4 \pm 1.3 \mathrm{mg}$ ET/100 $\mathrm{g}$ of dry sample) and germinated seeds was determined (27, $1 \pm 2.7 \mathrm{mg}$ ET/100 $\mathrm{g}$ of dry sample) of Amaranthus caudatus L. respectively. As noted, they found no differences between seeds and germinated seeds; In our study, we can see that in general, the germinated increased DPPH radical scavenging ability of up to 1.5 times. When the free radical scavenging ability of DPPH in five varieties expressed in $\mathrm{mmol} \mathrm{ET} / \mathrm{kg}$ dry matter was evaluated, the results were for Golden Giant (2.32 \pm 0.49$)$, Rawa (3.00 $\pm 0.40)$ Annapurna $(3.90 \pm 1.46)$, Oscar Blanco (4.64 \pm 0.57$)$ and Koniz $(2.46 \pm 0.51)$ respectively. ${ }^{22}$ In this case, despite having a low content of phenol compounds it had greater DPPH radical scavenging ability. In our research, the variety Oscar Blanco also had a good DPPH radical scavenging activity, but less than the Taray and Centenario varieties. On the other hand, regarding the free radical scavenging activity ABTS, the germinated seed of Centenario, Cristalino, Oscar Blanco and Taray varieties had higher scavenging activity without germinating seeds ( $\mathrm{p}$ $<0.05)$. Also, the variety Taray had the highest activity, followed by the Cristalino range and variety Oscar Blanco had the lowest activity.

The sequestering capacity increased between 1.9 times for variety Oscar Blanco to 2.6 times for the variety Taray, the average increase of 2.3 times. differences in the sequestering of ABTS radical by germinated phenolics of the four varieties $(\mathrm{p}<0.05)$. The Centenario and Oscar Blanco varieties had the lowest sequestering capacity and Cristalino varieties and Oscar Blanco had the highest sequestering capacity. The influence of germinated in phenolic content of the radical scavenging ability of ABTS was significant. Finally, the germinated seed of Centenario, Cristalino, Oscar Blanco and Taray varieties had higher iron reducing activity compared to non-germinated seeds. Also, the variety Taray had the highest activity, followed by the Cristalino range and variety Oscar Blanco had the lowest activity. The difference between varieties was significant $(\mathrm{p}<0.05)$. It was also noted that the Centenario and white varieties Oscar had the lowest reducing capacity; and Tamarisk and Cristalino varieties had the highest reducing activity. When comparing the scavenging activity between non-germinated seeds and germinated seeds, a highly significant difference $(\mathrm{p}<$ $0.05)$. It has reported the reducing capability of iron in seeds (55.3 $\pm 1.6 \mathrm{mg} \mathrm{ET} / 100 \mathrm{~g}$ of dry sample) and germinated seeds (122 \pm 11.1 mg ET/100 g of dry sample respectively) of Amaranthus caudatus L., without specifying the range; in which differences were observed in the reductive capacity of iron between seeds and germinated seeds, increasing to 2.2 times. ${ }^{23}$ In our report, we can see that in general, the germinated increased iron reducing capacity 1.7 times for variety Oscar Blanco and 2.5 times for variety Taray.

Consequently, as a result of this investigation it was shown that the germinated seeds of Amaranthus caudatus L. "Amaranth", increase the content of phenolic compounds, in turn producing an increase in antioxidant activity.

\section{CONFLICTS OF INTEREST}

The authors declare that they have no conflicts of interest.

\section{ACKNOWLEDGEMENTS}

Authors thanks to the Universidad Nacional de San Cristóbal de Huamanga for funding this research project and the facilities in the use of its laboratories. The National Institute of Agricultural Research and Experimentation-Ayacucho (INIEA-Ayacucho), for providing samples of Amaranthus caudatus L.

\section{Financial support and sponsorship}

Nil.

\section{ABBREVIATIONS}

DPPH: 1,1-Diphenyl-Picryl-Hidrazyl; ABTS: 2,2'-Azinobis Acid(3-Ethylbenzothiazoline)-6-Sulfonic Acid; FRAP: Ferric Reducing Antioxidant Power; TE: Trolox Equivalent.

\section{REFERENCES}

1. Castrillón - Arbelaez P, Delano P. Secondary Metabolism in Amaranthus spp - A Genomic Approach to Understand Its Responsiveness to Diversity and Stress in marginally Studied Agronomic Crops with High Potential. In: Abiotic and Biotic Stress in Plants. Recent Advances and Future Perspectives. India: In Tech. 2016;85-227.

2. Herrera-Calderon O, Alvarado-Puray C, Arroyo-Acevedo JL, Rojas-Armas JP Chumpitaz-Cerrate V, Hañari-Quispe R, et al. Phytochemical screening, total phenolic content, antioxidant, and cytotoxic activity of five peruvian plants on human tumor cell lines. Pharmacognosy Res. 2018; 10(2): 161-65.

3. Achigan-Dako EG, Sogbohossou O, Maundu P. Current knowledge on Amaranthus spp: research avenues for nutritional value and improve increase yield in leafy amaranthus in sub - Saharian Africa. Euphytica Springer. 2014;197(3):303-17

4. Herrera-Calderon O, Enciso-Roca E, Pari-Olarte B, Arroyo-Acevedo J Phytochemical screening, antioxidant activity and analgesic effect of Waltheria ovata Cav. roots in mice. Asian Pac J Trop Dis. 2016;6(12):1000-3.

5. Arnao M, Cano A, Acosta M. The hydrophilic and lipophilic antioxidant activity constribution to complete. Food Chemistry. 2001;73(2):239-44.

6. Benzie IFF, Strain JJ. The ferric reducing ability of plasma (FRAP) as a measure of antioxidant power: The FRAP assays. Analytical Biochemistry. 1996;239(1):7076.

7. Carciochi RA, Manrique G, Dinitrov K. Changes in antioxidant activity and phenolic composition germination of seeds During Quinoa (Chenopodium Quinoa Willd). International Food Research Journal. 2014;21(2): 767-73.

8. Klimczack I, Malecka M, Pacholek B. Antioxidant activity of ethanolic extrats of amaranth seeds. Nahrung/Food. 2012;46(3):84-6.

9. Kuskoski M, Asuero A, Troncoso A, Mancini - Filho J, Feti R. Application of various chemical methods to determine antioxidant activity in fruit pulp. Science Technol Aliment Campinas. 2005;25(4):26-32.

10. Uddin MS, Uddin GS, Begum MM, Begum Y, Herrera-Calderon O, Islam MM et al. Inspection of phytochemical content and in vitro antioxidant profile of Gnaphalium luteoalbum L.: An unexplored phytomedicine. Journal of Pharmacy and Nutrition Sciences 2017;7(3):136-46.

11. Almora-Pinedo $Y$, Arroyo-Acevedo JL, Herrera-Calderon O, Chumpitaz-Cerrate $V$, Hañari-Quispe $R$, Tinco-Jayo $A$, et al. Preventive effect of Oenothera rosea on N-methyl-N-nitrosourea- (NMU) induced gastric cancer in rats. Clin Exp Gastroenterol. 2017;10:327-32.

12. Herrera-Calderon O, Santiváñez-Acosta R, Pari-Olarte B, Enciso-Roca E, Montes VMC, Acevedo JLA. Anticonvulsant effect of ethanolic extract of Cyperus articulatus $\mathrm{L}$. leaves on pentylenetetrazol induced seizure in mice. Journal of Traditional and Complementary Medicine. 2018. 
13. Hossain MS, Uddin MS, Kabir MT, Akhter S, Goswami, S, Al Mamun A, et al. In Vivo Screening for Analgesic and Anti-Inflammatory Activities of Syngonium podophyllum L.: A Remarkable Herbal Medicine. Annual Research \& Review in Biology. 2017;16(3):1-12.

14. Arroyo-Acevedo J, Herrera-Calderón O, Chávez-Asmat R, Anampa-Guzmán A Chumpitaz-Cerrate V, Enciso-Roca E. Protective effect of Chuquiraga spinosa extract on $\mathrm{N}$-methyl-nitrosourea (NMU) induced prostate cancer in rats. Prostate international. 2017;5(2):47-52

15. Hossain MS, Uddin MS, Kabir MT, Begum MM, Koushal P, Herrera-Calderon $\mathrm{O}$, et al. In vitro screening for phytochemicals and antioxidant activities of Syngonium Podophyllum L.: An incredible therapeutic plant. Biomed Pharmacol J. 2017;10(3)

16. Uddin MS, Uddin GS, Begum MM, Begum Y, Herrera-Calderon O, Islam MM, et al. Inspection of phytochemical content and in vitro antioxidant profile of Gnaphalium luteoalbum L.: An unexplored phytomedicine. Journal of Pharmacy and Nutrition Sciences. 2017;7(3):136-46.

17. Herrera-Calderón O, Tinco-Jayo A Franco-Quino $C$, Chumpitaz-Cerrate $V$, Castro-Pari W, Pari-Olarte $\mathrm{P}$, et al. Antioxidant activity and cytotoxic profile of Chuquiraga spinosa Lessing on human tumor cell lines: A promissory plant from Peruvian flora. Asian Pac J Trop Dis. 2017;7(5):304-8.
18. Arroyo-Acevedo JL, Herrera-Calderon O, Rojas-Armas JP, ChumpitazCerrate V, Franco-Quino C, Hañari-Quispe R. Chuquiraga spinosa Lessing: A medicinal plant for gastric cancer induced by N-Methyl-N-Nitroso-Urea (NMU). Pharmacognosy Journal. 2018;10(1).

19. Pasko P, Barton H, Zagrodsky $P$, Gorinstein S, Folta M, Zachwieja Z Anhtocyanins, total polyphenols and antioxidant activity in amaranth and quinoa seeds and sprouts during their growth. Food Chemistry. 2009;115(3):994-998.

20. Prior R, Wu X, Schaich K. Methods for the determination Standardized of antioxidant capacity and dietary supplements. Journal of Agricultural and Food Chemistry. 2005;53(10):4290-302.

21. Rubio N, Guerrero G. Effect of temperature on packaging and shelf life of outbreaks of amaranth (Amaranthus caudatus L.) for human consumption, Quito - Ecuador: University of the Americas. 2016.

22. Alvarez-Jubete L. Wijngaard H, Arendt EK, Gallagher E. Polyphenol composition and in vitro antioxidant activity of amaranth, quinoa, buckwheat and wheat as Affected by sprouting and baking. Food Chemistry. 2010;119(2):770-78.

23. Aphalo P, Martinez, Añón MC. Amaranthus sprouths. A potential health Promoting Natural and nutritive food. International Journal of Food Properties. 2015;18(12):2688-698.

\section{GRAPHICAL ABSTRACT}
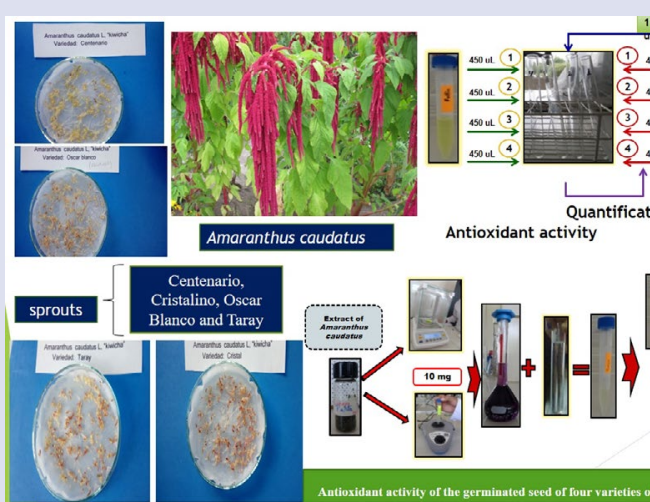

Quan
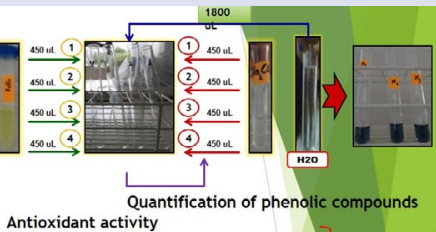

Q

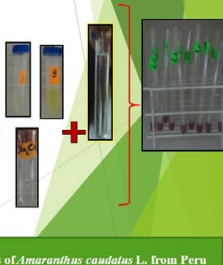

\section{SUMMARY}

- Antioxidant activity of the germinated seed of four varieties of Amaranthus caudatus L. from Peru were assessed by using in vitro methods such as ABTS, FRAP and DPPH.

- Varieties of Amaranthus seeds as: "Taray", "Oscar Blanco", "Cristalino", "Centenario" were provided by the National Institute for Agricultural Research and Experimentation of Ayacucho (INIEA-Ayacucho).

- Cristalino and Taray varieties had the highest content of total phenolics (GAE 32.92 and $35.00 \mathrm{mg} / \mathrm{g}$ sample).

- Cristalino variety had higher content of flavonoids $(580.95 \mathrm{mg} \mathrm{QE} / \mathrm{g}$ ): Cristalino and Taray varieties showed greater scavenging activity of DPPH radical (151.85 and $151.38 \mathrm{mg} \mathrm{TE} / \mathrm{g}$ sample), ABTS (178.09 and $180.18 \mathrm{mg}$ TE/g sample); and reducing capacity of the ferric ion (FRAP) (132.75 and $136.42 \mathrm{mg} \mathrm{TE} / \mathrm{g}$ of sample).

\section{ABOUT AUTHORS}
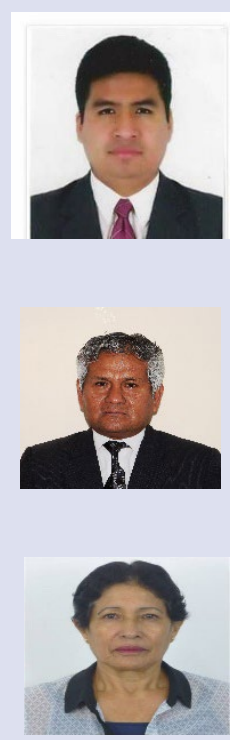

Oscar Herrera-Calderon: He is a professor and researcher in the Faculty of Pharmacy and Biochemistry, Universidad Nacional Mayor de San Marcos, Lima, Peru. His expertise is Natural products with anticancer properties, pharmacokinetic studies and the use of animals models to discover new potential drugs against different types of cancer.

Javier Enrique Aguilar-Felices: He works in the Laboratory of Pharmacognosy, Faculty of Health Sciences, Universidad Nacional del San Cristóbal de Huamanga, Ayacucho, Peru. His expertise is Natural products with antioxidant properties.

Marta Romero-Viacava: She works in the Laboratory of Botany, Faculty of Biological Sciences, Universidad Nacional San Cristóbal de Huamanga, Ayacucho, Peru. 


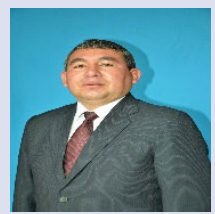

Edwin Enciso-Roca: He works in the Laboratory of toxicology, Faculty of Health Sciences, Universidad Nacional del San Cristóbal de Huamanga, Ayacucho, Peru. His expertise is Natural products with antioxidant properties.

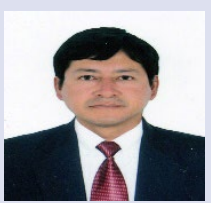

Pablo Comun-Ventura: He works in the Laboratory of quality control, Universidad Nacional San Cristóbal de Huamanga, Ayacucho, Peru.

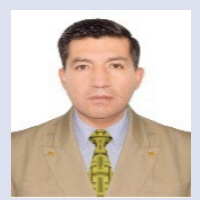

Ricardo Yuli-Posadas: He works in the research direction, Universidad Continental, Huancayo, Peru.

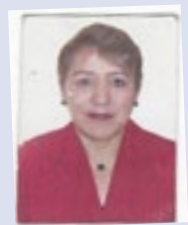

Luz Chacaltana-Ramos: She is a professor and researcher in the Faculty of Pharmacy and Biochemistry, Universidad Nacional San Luis Gonzaga de Ica.

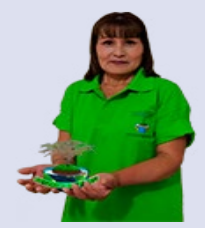

Bertha Pari-Olarte: She is a professor and researcher in the Faculty of Pharmacy and Biochemistry, Universidad Nacional San Luis Gonzaga de Ica.

Cite this article: Aguilar-Felices EJ, Romero-Viacava M, Enciso-Roca E, Herrera-Calderon O, Común-Ventura P, Yuli-Posadas RA, et al. Antioxidant Activity of the Germinated Seed of Four Varieties of Amaranthus caudatus L. from Peru. Pharmacog J. 2019;11(3):588-93. 